\section{Consumer Survey Identifies Plant Management Awareness and Added Value of Dogwood Powdery Mildew Resistance}

\author{
William E. Klingeman, ${ }^{1}$ \\ David B. Eastwood, ${ }^{2}$ \\ John R. Brooker, ${ }^{2}$ \\ Charles R. Hall, ${ }^{2}$ \\ Bridget K. Behe, ${ }^{3}$ and \\ Patricia R. Knight ${ }^{4}$
}

\begin{abstract}
AdDITIONAL INDEX WORDS. flowering dogwood, Cornus florida, integrated pest management, sustainable landscape, willingness-to-pay
\end{abstract}

Summary. A survey was administered to assess plant characteristics that consumers consider important when selecting landscape plants for purchase. Visitors to home and garden shows in Knoxville and Nashville, Tenn.; Detroit, Mich.; and Jackson, Miss., completed 610 questionnaires. Respondents also indicated their familiarity with integrated pest management (IPM) concepts, pest control philosophy, recognition of flowering dogwood (Cornus florida) pests and diseases, including dogwood powdery mildew (Microsphaera pulchra), and willingness-to-pay a price differential for a powdery-mildew-resistant flowering dogwood. Fewer than half of the respondents in any city indicated familiarity with IPM, although they were familiar with organic farming and pest scouting components of an IPM program. Willingness-to-pay was relatively consistent across all four locations. The uniformity of average tree premiums, which ranged

${ }^{1}$ Assistant professor, Plant Sciences Department, University of Tennessee, Knoxville, TN 37996-4500; email: wklingem@utk.edu.

${ }^{2}$ Professor, Department of Agricultural Economics, University of Tennessee, Knoxville, TN.

${ }^{3}$ Professor, Department of Horticulture, University of Michigan, East Lansing, MI 48824-1325. 37996-4500.

${ }^{4}$ Associate research professor. South MS Branch Experiment Station, Mississippi State University, P.O. Box 193, Poplarville, MS 39470. from \$11.87 in Jackson to \$16.38 in Detroit, supports the proposition that customers are willing to pay a substantially higher price for a landscape tree that will maintain a healthier appearance without the use of chemical sprays. Factors affecting consumer demand for landscape nursery products and services can be paired with consumer awareness of IPM terminology and practices to create an effective market strategy for newly developed powdery-mildew-resistant dogwood cultivars.

$\mathrm{T}$ To remain competitive and profitable, growers, retailers and landscape managers need to factor consumer perception and awareness about ornamental plants and plant management expectations into effective marketing messages (Becker et al., 1997). This strategy includes building competitive strength by providing products that fill market gaps. Among surveyed landscape architects, $21 \%$ identified development of new plant varieties that met specific needs as a necessary improvement opportunity for the industry (Garber and Bondari, 1992). As such, many of the market gaps in the landscape industry could be filled with plants that possess disease- or pest-resistance characteristics. One such example is the recent development of dogwoods that are resistant to powdery mildew.

Since 1994, dogwood powdery ildew has become a serious problem for nursery producers and landscape managers (Klein et al., 1998; Ranney et al., 1995). As a nursery product, dogwoods are important to southeastern U.S. growers. In Tennessee, combined retail and wholesale sales accounted for $23.2 \%$ of the dogwood trees sold in the U.S. (U.S. Dept. Agr., 1999). Powdery mildew challenges large-scale production by reducing seedling vigor, which has virtually halted cultivar production by budding on infected trees (Windham, 1996). As a result, Tennessee nursery plant producers are adversely affected by the increased cost of dogwood production. In 1984, estimated cost of pest and disease control in budded flowering dogwoods was about $\$ 717 /$ ha $(\$ 290 /$ acre $)$ over a 3year period (Badenhop et al., 1985). Current estimates place this figure closer to $\$ 5471 /$ ha (\$2214/acre) with the increase attributed largely to powdery mildew management (C.R.
Hall, personal communication). Despite availability of pesticides that control these diseases, nursery sales and production offlowering dogwoods has continued to decline due to diminishing consumer demand and increased likelihood of tree loss and need for intensive disease management. In the landscape, dogwood powdery mildew results in limited growth and reduced vigor and reproduction among mature dogwoods (Windham, 1996). Awareness of dogwood anthracnose (Discula destructiva) and powdery mildew diseases has spread to the general public through articles in popular press and news sources that present only bleak predictions of future landscape potential for these trees (Davis, 1997; Englander, 1997).

Scientists at the University of Tennessee Institute of Agriculture have identified and quantified powdery mildew resistance among flowering dogwood seedlings that were collected from commercial nursery fields in Tennessee (Windham, 1996; Windham and Witte, 1998; Windham et al., 2003). Plant patent applications for the three most promising clones were approved by the U.S. Patent Office. These disease-resistant cultivars will be released to commercial producers by the University of Tennessee (Witte et al., 1999).

To date, research efforts have not quantified consumer perceptions of the value of disease-resistant plant materials. Nursery producers have little unbiased guidance by which they can establish appropriate economic value, in terms of wholesale or retail prices, of pest- or disease-resistant plant materials. Knowledge about consumer awareness of pests and diseases and the importance that consumers place on ornamental characteristics at point-ofpurchase also remains limited. Focused awareness of criteria that homeowners use to select trees, shrubs, perennials, or annuals for their landscapes could be used to improve commercial marketing practices and to establish optimal pricing schedules for disease- or pestresistant ornamentals (Wertenbroch and Skiera, 2002).

Discovery and development of disease-resistant flowering dogwoods is expected to renew consumer and nursery producer confidence in this valuable ornamental crop. However, successful marketing and optimized pricing schedules for powdery-mildew- 


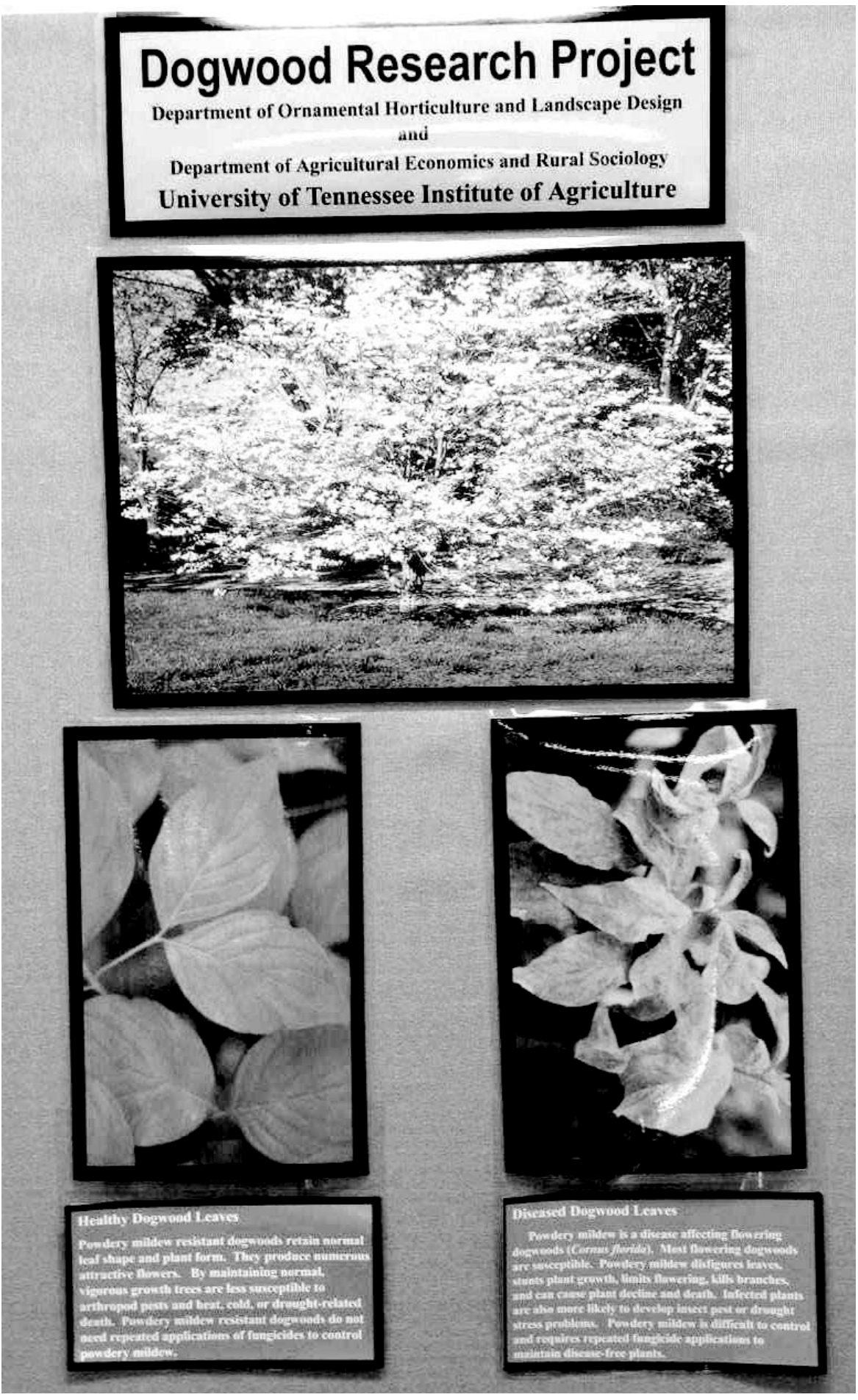

Fig. 1. Master Gardener volunteers solicited consumer participation in the "Dogwood Research Project" at "home and garden" shows at urban locations in Knoxville and Nashville, Tenn.; Detroit, Mich. and Jackson, Miss. In total, 610 individual show attendees completed and returned the two-page survey.

resistant dogwoods requires knowledge of factors that affect consumer demand for landscape nursery products and services. In addition, consumer decisions to choose plants will be influenced by their level of awareness for IPM terminology and practices. Thus, the objective of this study was to identify consumer awareness and perceptions about these issues. This survey research was also designed to reveal consumer willingness to pay a price differential for a flowering dogwood tree that is resistant to powdery mildew.
Nursery producers and ornamental plant researchers will benefit from a greater understanding of consumer comprehension regarding integrated pest management concepts. In turn, consumer awareness can be incorporated into an effective market message (van der Sluis, 2002). Moreover, consumer willingness toincur economic and aesthetic costs in order to limit pesticide use in the landscape will become an important factor in future development, marketing, and pricing of pest and disease-resistant ornamental plant materials (Klingeman et al., 2000).

\section{Materials and Methods}

In Spring 2000, a two-page survey questionnaire and graphic display were created for use at home and garden trade shows open to the general public. The display included a photograph of a flowering dogwood in full flower, as well as pictures of healthy and diseased dogwood leaves (Fig. 1). Brief statements that described the appearance and outcome of the disease were included on the display in easy-to-read language and print. The surveys were conducted at the Dogwood Arts Festival Home and Garden Show in Knoxville, Tenn.; the Lawn and Garden Show in Nashville, Tenn.; Bloomfest, a home and garden show in Detroit, Mich.; and the Garden and Patio Show in Jackson, Miss. during Fall 2000 and Winter 2001.

As they passed by the display at each location, individuals were asked at random to complete the questionnaire (Fig. 2). No incentives were offered to survey participants. Master Gardener volunteers were enlisted to solicit attendee participation in partial fulfillment of their hours-of-service requirement. As survey enumerators, Master Gardeners were informed of the potential bias that could result from discussing questions and were asked to limit such discussion until after participants completed their surveys.

From each venue, completed survey forms were returned to the University of Tennessee. Responses were encoded in concordance with the questionnaire and entered into Epi Info 6.04 software (Centers for Disease Control, 1994). Data reflected a random sample and were subjected to chi-square analysis in SAS (SAS Institute, 1985).

\section{Results and Discussion}

Demographic profile. Survey participants returned 147, 269, 132, 
Fig. 2. In 2000, a consumer survey was conducted at four separate home and garden shows in urban areas of Tennessee, Mississippi, and Michigan to determine the added-value of powdery mildew resistance in flowering dogwoods and to provide baseline knowledge for developing marketing strategies for pest- and disease-resistant ornamentals. Surveys yielded information about awareness of integrated pest management (IPM)-related terms. Home and garden show attendees were asked by Master Gardener volunteers to provide responses to the following survey instrument $(1 \mathrm{ft}=0.3 \mathrm{~m}, 1 \mathrm{inch}=2.54$ $\mathrm{cm}, 1 \mathrm{gal}=3.8 \mathrm{~L}, 1$ acre $\left.=0.4 \mathrm{ha}, 1 \mathrm{ft}^{2}=0.093 \mathrm{~m}^{2}\right)$.

\section{University of Tennessee Landscape Plant Survey}

All responses are voluntary and will remain anonymous

After viewing the poster on display and reading the information, assume your favorite retailer is selling flowering dogwood trees (Cornus florida) that are 5 feet tall, have a 1 -inch trunk diameter, are sold in a 5 -gallon container, which are the typical size produced for consumers at garden centers and mass merchandisers.

1. How much more would you be willing to pay for an identically sized flowering dogwood that is resistant to powdery mildew?

$\$ 0|||| \$ 5|||| \$ 10|||| \$ 15|||| \$ 20|||| \$ 25|||| \$ 30$

2. Do you presently: [ ] own a home, [ ] rent a home or apartment, [ ] plan to buy a home within 2 years?

3. Do you currently have a dogwood in your landscape? [ ] Yes, [ ] No

If yes, are the majority of your dogwoods in [ ] Sun; [ ] Part Shade; [ ] Shade

Do any of your dogwoods have (check all that apply): powdery mildew

dogwood borer injury
trunk cracks/splits anthracnose (leaf spots) dogwood twig gall midge

_ don't know drought injury (brown leaf edges)

4. About how much did you spend last year (1999) in your home garden and landscape on:

\begin{tabular}{|c|c|c|c|c|c|}
\hline$\$$ & annuals \& perennials; & $\$$ & shrubs; & $\$$ & trees; \\
\hline$\$$ & seeds; & $\$$ & _equipment; & $\$$ & mulch; \\
\hline$\$$ & spray service; & $\$$ & fertilizer; & $\$$ & esticides; \\
\hline$\$$ & mowing/maintenance; & $\$$ & other & & \\
\hline
\end{tabular}

5. Describe your yard (check all that apply). Estimate its size in ___ Acres or __ Sq. Ft.

[ ] wooded lot, [ ] mostly open yard, [ ] perennial beds, [ ] vegetable or herb garden

[ ] landscaped borders, [ ] annual beds, [ ] grass lawn, [ ] container plantings.

6. Is your lawn and landscape maintained: [ ] by yourself or a family member;

[ ] by hired help; [ ] left to grow on its own.

7. Are you content with the appearance of your landscape? [ ] Yes, [ ] No

8. Do you regularly read a gardening/grower magazine? [ ] Yes, [ ] No

If yes, which ones?

9. Rank the TOP 5 reasons you pick landscape TREES (Rank only $5 ; 1=$ most important). length of flowering period availability water needs longevity sun/shade preferences of tree resistance to insects/mites familiarity easy maintenance fruit growth rate attracts butterflies/beneficial insects winter appearance

flower color

_ disease resistance oil preferences size/shape native

attracts birds/animals
leaf color
flowering season
University tested
to create shade
other:

10. To reduce pesticide use, what level of injury to plants in your landscape would you accept?
[ ] high, [ ] moderate, [ ] low,
[ ] none

11. Are you familiar with these terms or concepts?

Term or Concept

Pest Tolerance

Biological Control

Mycorrhizal Fungi

Insecticide Resistance

Integrated Pest Management (IPM)

Pest Scouting/Monitoring

$\begin{array}{ll}\text { Never Heard It } & \text { Sounds Familiar } \\ {[]} & {[]} \\ {[]} & {[]} \\ {[]} & {[]} \\ {[]} & {[]} \\ {[]} & {[]} \\ {[]} & {[]}\end{array}$

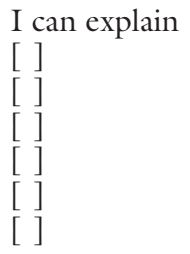


Fig. 2. Continued from p. 277.

11. Continued. Are you familiar with these terms or concepts?

Term or Concept Never Heard It

Beneficial Insects

Urban Landscape

Land Stewardship

Organic Gardening

Pheromone Trapping

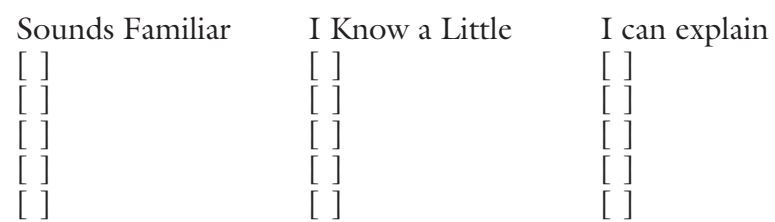

12. If you were choosing plants for your landscape, what would your TOP $\mathbf{5}$ considerations be? (Rank only 5 ; $1=$ most important) insect/mite resistance familiarity

water requirements

to try a new plant

sun/shade requirements

soil preferences

season of bloom

winter appearance

plant quality

longevity

attracts butterflies/beneficial insects

University tested

familiarity
size/shape
leaf color
availability
native
length of flowering period
disease resistance
disy maintenance
easy
attracts birds/animals
other:

13. Where do you shop for landscape plants? (Check all that apply) retail chain

landscaper/contractor independent/specialty garden center mail order catalog farm market/truck stand grocery

direct from nursery other

14. In your opinion, is the quality of landscape plants you purchase:

[ ] excellent, [ ] good, [ ] mediocre, [ ] poor, [ ] not sure

15. Are you satisfied with the performance of these plants in the landscape?

[ ] always, [ ] often, [ ] sometimes, [ ] never, [ ] not sure

16. Name a Beneficial (or Environmentally Helpful ... . ): insect bird plant/flower

17. Are you [ ] Male, [ ] Female?

18. What is your approximate age? [ ]15-24; [ ]25-34; [ ]35-44; [ ]45-54; [ ]55-64; [ ]65+

19. Estimate your Gross Household Income before taxes this past year:

[ ] less than $\$ 25,000$ [ ] $\$ 25,000-\$ 49,999$

[ ] $\$ 75,000-\$ 99,999 \quad[$ [ ] $\$ 100,000-\$ 124,999$

[ ] $\$ 50,000-\$ 74,999$

[ ] $\$ 125,000$ or more

and 62 completed questionnaires in Knoxville, Nashville, Detroit, and Jackson, respectively. Survey participants were significantly more likely to be female in Detroit and Jackson, where the female-to-male ratios were $4: 1$ and $7: 3$, respectively $\left(\chi^{2}=28.85, \mathrm{df}=3\right.$, $P<0.001)$. In all four cities, current home-ownership ranged from 92\% among survey participants in Knoxville to $98 \%$ in Jackson. With the exception of Detroit, most respondents were "discontent" with the landscapes they managed $\left(\chi^{2}=11.34, \mathrm{df}=3, P=0.010\right)$. The greatest degree of discontent was evident among Knoxville participants, for whom $68 \%$ saw room for improvement. Only 41 and $43 \%$ of Nashville and Jackson participants, respectively, were "content" with their landscapes. In Detroit, a slight majority of survey participants was content with the appearance of their landscapes.

DogwoOds IN THE LANDSCAPE. Among Tennessee participants, dogwood trees were an ornamental staple with $80 \%$ or more of the landscapes featuring dogwoods. By contrast, $53 \%$ of Detroit respondents had no dogwoods in their landscapes. These differences in dogwood occurrence were significant $\left(\chi^{2}=67.62, \mathrm{df}=3, P\right.$ $<0.001)$. The majority of flowering dogwoods are produced in southern states (U.S. Dept. Agr., 1999). Although these trees are described as less adaptable to the Michigan climate (Dirr, 1998), they are often planted in Michigan landscapes. In all cities, respondents who had dogwood trees in their landscape maintained most of them under full or partial shade.
Pest/disease recognition and LANDSCAPE MANAGEMENT PHILOSOPHY. ACcording to the respondents who managed a dogwood in their landscapes, nearly one-fourth to one-third were unable to comment on possible pest or disease problems (Table 1). Occurrence of powdery mildew on dogwoods was significantly different among cities $\left(\chi^{2}=17.35, \mathrm{df}=3, P<0.001\right)$. This disease was present on $35 \%$ and $23 \%$ of dogwoods maintained in Nashville and Jackson landscapes, respectively. For Knoxville and Detroit respondents, $18 \%$ and $15 \%$ reported powdery mildew as a problem, respectively. When identifying other potential management problems, drought injury was found to be significantly lower on the Detroit respondents' dogwoods (11\%) than the $26 \%$ to $34 \%$ reported for the 
other three cities $\left(\chi^{2}=12.99, \mathrm{df}=3, P\right.$ $<0.005)$. Trunk cracks or splits did not differ among cities. Responses regarding dogwood anthracnose leaf spots were significantly different among the four cities, ranging a high of $20 \%$ in Knoxville to only $2 \%$ in Jackson $\left(\chi^{2}=\right.$ 11.60, $\mathrm{df}=3, P<0.009)$. Among all cities, $9 \%$ or less identified borers as a concern, and $2 \%$ or fewer respondents indicated problems with dogwood twig gall midge (Resseliella clavula).

Survey respondents were largely self-reliant for identifying pest and disease problems, which were selfdiagnosed by $73 \%$ of Knoxville respondents and $84 \%$ of Nashville respondents. Friends were more frequently identified as pest or disease diagnosticians than were university extension personnel. In any city, 15\% or fewer respondents were assisted with pest or disease problems by extension personnel. Detroit and Jackson respondents were significantly more likely to consult a nursery or garden center to identify pest and disease problems than were their Tennessee counterparts $\left(\chi^{2}\right.$ $=9.68, \mathrm{df}=3, P<0.022)$. Where pest and disease problems required pesticide management, significantly more
Tennessee and Jackson respondents applied chemical controls themselves than Detroit respondents $\left(\chi^{2}=10.33\right.$, $\mathrm{df}=3, P=0.016)$. Less than one-fourth of respondents used commercial applicators (data not shown).

Survey participants in all locations reported a similar willingness to tolerate hypothetical landscape plant injury in order to limit pesticide use in the landscape $\left(\chi^{2}=6.59, \mathrm{df}=9, P=0.679\right)$. While only $6 \%$ reported a willingness to accept high levels of injury, $44 \%$ of all respondents indicated that they would tolerate moderate injury on landscape plants. Only $8 \%$ of respondents were unwilling to tolerate any amount of plant injury.

KNOWLEDGE OF IPM. Eleven terms or phrases that are frequently associated with landscape IPM were presented to survey participants (Table 2). Participants responded to the phrases with the following choices: never heard of [it], sounds familiar, "I know a little [about it], and I can explain [it]. The proportions of respondents who reported knowing a little or being able to explain the meaning of a term were combined. Unless a response was marked on the questionnaire, the assumption was that the respondent did not know the meaning of the term. Of the 11 terms, there were only five where the differences among the cities were significant: pest scouting $\left(\chi^{2}=18.47\right.$ $\mathrm{df}=3, P<0.001)$, pest tolerance $\left(\chi^{2}\right.$ $=16.00, \mathrm{df}=3, P=0.001)$, organic farming $\left(\chi^{2}=10.63, \mathrm{df}=3, P<0.014\right)$, insecticide resistance $\left(\chi^{2}=8.68, \mathrm{df}=\right.$ $3, P<0.034)$, and beneficial insects $\left(\chi^{2}=10.79, \mathrm{df}=3, P<0.012\right)$. For each of these terms, lowest percentages of familiarity were reported for Knoxville. With respect to organic farming, respondents in Nashville and Detroit were more familiar with the term than respondents in Knoxville and Jackson. In general, respondents were least familiar with the terms mycorrhizal fungi, pheromone trapping, beneficial insects, and IPM. Overall, Nashville and Detroit seemed to have the more knowledgeable respondents because the percentage of familiarity was highest in Nashville for six of the 11 terms and highest in Detroit for the other five terms.

Due to ex ante expectations of responses to IPM-related term recognition, participants were also asked to report if they read gardening magazines

Table 1. Percent of consumer attendees at four separate home and garden shows in 2000 who responded with a positive answer to the question: Do any of the dogwoods in your landscape have (the following pest/disease problems). ${ }^{z}$

\begin{tabular}{|c|c|c|c|c|c|}
\hline Disease & Knoxville & Nashville & Detroit & Jackson & $\chi^{2}$ \\
\hline Powdery mildew $(\%)$ & 18 & 35 & 15 & 23 & $17.35^{* * *}$ \\
\hline Trunk cracks or splits $(\%)$ & 30 & 33 & 21 & 23 & $4.02^{\mathrm{Ns}}$ \\
\hline Anthracnose leaf spots (\%) & 20 & 14 & 7 & 2 & $11.60^{* *}$ \\
\hline Borers $(\%)$ & 8 & 9 & 3 & 5 & $3.14^{\mathrm{Ns}}$ \\
\hline Dogwood twig gall midge $(\%)$ & 1 & 2 & 2 & 2 & $0.77^{\mathrm{Ns}}$ \\
\hline
\end{tabular}

${ }^{2}$ Data are presented for only respondents who reported that they had a dogwood in their landscape. Respondents were permitted to check all that applied.

$\mathrm{Ns}, * *, * * *^{*}$ Nonsignificant or significant $\chi^{2}$ at $P<0.01$ or 0.001 , respectively.

Table 2. Percent of consumer attendees at four separate home and garden shows is 2000 who indicated that they either [knew] a little or [were] able to explain the following integrated pest management (IPM)-related terms. ${ }^{\mathrm{Z}}$

\begin{tabular}{|c|c|c|c|c|c|}
\hline IPM-related term & Knoxville & Nashville & Detroit & Jackson & $\chi^{2}$ \\
\hline Participants who responded (no.) & 147 & 269 & 132 & 62 & \\
\hline Pest tolerance $(\%)$ & 46 & 66 & 58 & 56 & $16.00^{* * *}$ \\
\hline Biological control (\%) & 51 & 58 & 55 & 45 & $3.97^{\mathrm{Ns}}$ \\
\hline Insecticide resistance $(\%)$ & 50 & 64 & 63 & 63 & $8.68^{\star}$ \\
\hline $\operatorname{IPM}(\%)$ & 32 & 33 & 40 & 24 & $5.17^{\mathrm{Ns}}$ \\
\hline Beneficial insects (\%) & 24 & 30 & 42 & 29 & $10.79^{* *}$ \\
\hline Land stewardship (\%) & 42 & 49 & 42 & 48 & $2.46^{\mathrm{Ns}}$ \\
\hline Organic farming $(\%)$ & 68 & 80 & 81 & 71 & $10.63^{* *}$ \\
\hline Pheromone trapping (\%) & 24 & 27 & 36 & 23 & $5.70^{\mathrm{Ns}}$ \\
\hline
\end{tabular}

${ }^{2}$ Respondents indicating that they never heard of a term or it sounds familiar were excluded.

ss,,,$++*+*+$ Nonsignificant or significant $\chi^{2}$ at $P<0.05,0.01$ or 0.001 , respectively. 
Table 3. Survey participants were presented lists of horticultural factors to consider when selecting trees or shrubs, perennials and annuals. Respondents indicated which factors were the five most important when selecting these plants for their landscapes. Percentages correspond to the reported importance of each factor summed among all four locations.

\begin{tabular}{|c|c|c|}
\hline Factor & Trees & $\begin{array}{c}\text { Shrubs, } \\
\text { perennials, } \\
\text { and annuals }\end{array}$ \\
\hline Total number of responses (all cities) & 610 & 610 \\
\hline Size and shape (\%) & $51^{z}$ & $39^{y}$ \\
\hline Ease of maintenance $(\%)$ & 45 & 39 \\
\hline Attracts birds and animals (\%) & 34 & 31 \\
\hline Flower color $(\%)$ & 33 & $\mathrm{NA}^{\mathrm{x}}$ \\
\hline Flowering season $(\%)$ & 32 & 49 \\
\hline Leaf color $(\%)$ & 31 & 22 \\
\hline Sun or shade preference $(\%)$ & 25 & 43 \\
\hline To create shade $(\%)$ & 25 & NA \\
\hline Availability (\%) & 23 & 14 \\
\hline Disease resistance (\%) & 22 & 19 \\
\hline Longevity (\%) & 21 & 23 \\
\hline Winter appearance $(\%)$ & 20 & 17 \\
\hline Native $(\%)$ & 20 & 14 \\
\hline Attracts butterflies and beneficial insects (\%) & 17 & 27 \\
\hline Growth rate $(\%)$ & 17 & NA \\
\hline Water needs (\%) & 16 & 22 \\
\hline Length of flowering period (\%) & 14 & 43 \\
\hline Familiarity $(\%)$ & 14 & 13 \\
\hline Soil preferences $(\%)$ & 10 & 11 \\
\hline Fruit $(\%)$ & 10 & NA \\
\hline Insect and mite resistance (\%) & 9 & 10 \\
\hline University tested $(\%)$ & 1 & 2 \\
\hline To try a new plant $(\%)$ & NA & $24^{\mathrm{w}}$ \\
\hline Plant quality (\%) & NA & 2 \\
\hline Other factors $(<2 \%$ each $)(\%)$ & 5 & 4 \\
\hline
\end{tabular}

${ }^{2}$ The only tree factor that differed among cities. Knoxville (51\%); Nashville (48\%); Detroit (61\%); and Jackson $(40 \%)$ respondents ranked size and shape among their most important considerations. Significant $\chi^{2}$ at $P<0.05$ $\left(\chi^{2}=8.67, \mathrm{df}=3, P=0.034\right)$

Knoxville (36\%); Nashville (41\%); Detroit (45\%); and Jackson (24\%) participants responded differently but selected size and shape among their most important considerations when selecting shrubs, perennials or annuals for their landscapes. Significant $\chi^{2}$ at $P<0.05\left(\chi^{2}=8.96, \mathrm{df}=3, P=0.029\right)$.

"Cells designated by "NA" indicate that factors were not included in the list provided for the plant category trees or shrubs, perennials, and annuals.

"Knoxville (16\%); Nashville (27\%); Detroit (31\%); and Jackson (18\%) participants selected to try a new plant differently when choosing shrubs, perennials or annuals for their landscapes. Significant $\chi^{2}$ at $P<0.01\left(\chi^{2}=10.94\right.$, $\mathrm{df}=3, P=0.012$

and, if so, which ones. Responses about gardening and grower magazine readership were varied. Significantly more Detroit participants indicated that they regularly read gardening magazines $\left(\chi^{2}\right.$ $=13.83, \mathrm{df}=3, P=0.003)$. By contrast, only one-third of Nashville participants indicated magazine readership. Knoxville respondents were almost evenly split. The list of magazines most frequently identified by the respondents included 1) Better Homes and Gardens, 2) Organic Gardening, 3) Southern Living Magazine, 4) Garden Gate, and 5) Horticulture, which represent the most accessible educational channels. The diversity of magazines that were reported suggests broad reader interest (data not shown).

FACTORS AFFECTING PLANT PURCHASES. Participants were asked to rank from a list the top five factors that directed their choices when purchasing trees and shrubs, perennials, or annuals for their landscapes (Table 3). Because of the large number of respondents who simply checked a factor on the questionnaire instead of ranking five items from 1 through 5 , all responses with a number or a check mark were considered to be an indication that the factor wasimportant. Key considerations when purchasing trees were consistent among cities. Size and shape was the only factor with a significant chi-square value $\left(\chi^{2}=\right.$ $8.67, \mathrm{df}=3, P=0.034)$, and it was also the leading factor in every city, ranging from $40 \%$ in Jackson to $61 \%$ in Detroit. The next five, with only slight variation among the locations, included ease of maintenance, attractiveness to birds and animals, flower color, flowering season, and leaf color. Respondents in each city were uniform in their opinions that being university tested was the least important consideration. In all cities, insect/mite resistance and fruit failed to rank among the top 15 reasons why consumers selected trees for their landscapes.

In addition to considerations that consumers deemed important when purchasing trees, respondents were asked to identify the key criteria used for selecting shrubs, perennials, and annuals for landscape use. Flowering season, sun/shade requirements, length of flowering period, size and shape, ease of maintenance, and attractiveness to birds and animals were the leading factors in all four cities. In addition, butterfly and beneficial insect attraction was seventh among Nashville and Detroit respondents. As with trees, insect/mite resistance, soil preferences, and university tested were never ranked among the top 15 considerations. Size and shape demonstrated significant variation among the cities $\left(\chi^{2}=8.96, \mathrm{df}=3, P=0.029\right)$. Jackson respondents ranked it eighth instead of fourth as in the other three cities. One other factor, to try a new plant had a significant chi-square value indicating statistical dependence among the responses $\left(\chi^{2}=10.94, \mathrm{df}=3, P\right.$ $=0.012)$. The percentage of respondents in Detroit noting this factor as important was almost twice as high as the respondents in Knoxville, $31 \%$ to $16 \%$, respectively.

An add-on question to the survey asked consumers to name a beneficial or environmentally helpful insect, bird, and plant. When responses from all cities were combined, 305 participants identified ladybugs (e.g., Coccinella spp.) as beneficial, followed by praying mantises (e.g., Mantis and Tenoderaspp.) (52 responses), and bees (Apisspp.) (28 responses). Consumers were less likely to identify specific birds and plants as beneficial or environmentally helpful. Purple martins (Progne subis) were named by 77 participants, bluebirds (Sialia spp.) by 58 , and hummingbirds (Archilochus spp.) by 54 respondents. Marigolds (Tagetes spp.) were identified by 65 respondents and 25 people listed butterfly bush (Buddleia spp.).

RETAIL SOURCE, PERCEPTION OF PLANT QUALITY, AND GREEN INDUSTRY CONSUMPTION. Survey participants were asked to indicate where they purchased plants. Retail chains and independent garden centers were identified by $50 \%$ 
or more of respondents in all four cities as their primary source of plants. Nashville residents were most likely to shop at retail chain stores $\left(\chi^{2}=\right.$ 12.64, $\mathrm{df}=3, P<0.006)$. Third in overall frequency were nurseries, as 40 to $55 \%$ of the respondents reported purchasing some portion of their landscape plants directly from the nursery grower. Less than $25 \%$ of Tennessee respondents identified a farm market or truck stand as a place they shopped, while a third of Detroit respondents patronized this market segment $\left(\chi^{2}=\right.$ $16.53, \mathrm{df}=3, P<0.001)$. Nearly half of Nashville and Detroit respondents purchased plants by mail order, which was a significantly higher proportion of purchases than by respondents in Knoxville and Jackson $\left(\chi^{2}=16.53\right.$, df $=3, P<0.001)$. Grocery stores were identified as a source of plants by fewer than $10 \%$ of all respondents, regardless of surveyed city. Only $11 \%$ to $25 \%$ of respondents employed a landscaper or contractor to supply their landscape plants.

Participants were also asked to rate the quality of plants that they purchased for their landscapes. While only $5 \%$ of Nashville residents were unsure of the quality of plant materials that they had purchased, a significantly larger number $(23 \%)$ of respondents in Jackson were not sure $\left(\chi^{2}=32.91, \mathrm{df}=9, P\right.$ $<0.001$ ). About $16 \%$ of Tennessee respondents and half as many Detroit and Jackson participants indicated that their purchased plants were poor or mediocre in quality. Most respondents, from $63 \%$ in Jackson to $70 \%$ of Nashville participants, assessed the quality of the plants they purchased as good. Similarly, $15 \%$ or fewer of all respondents rated their plants as being of excellent quality.

Participants reported a range of 1999 expenditures on landscape-related items and services from $\$ 552$ in Jackson, Miss., to \$1058 in Nashville, Tenn. For each city, more respondents reported purchasing annuals and perennials than inputs in any other category. Detroit respondents spent the most for trees with an average annual expenditure value of $\$ 474$ (data not shown).

AdDed VAlue of POWDery MiLdeW RESISTANCE. Respondents were asked how much more they would be willing to pay for a powdery-mildew-resistant, 5 -ft-tall $(1.5-\mathrm{m})$ flowering dogwood with a 1 -inch $(2.5-\mathrm{cm})$ trunk caliper that was sold in a 5 -gal (18.9-L) container. Consumers indicated a range in the added-value of powdery mildew resistance in flowering dogwood from $\$ 11.87 \pm 7.74$ in Jackson to $\$ 16.38$ \pm 8.11 in Detroit. Willingness-to-pay for added-value of the mildew resistance paralleled average consumer tree expenses that were reported by area respondents. Consumers who reported spending more on tree purchases indicated a higher willingness-to-pay.

INCORPORATING IPM INTO MARKETING STRATEGIES FOR PEST- AND DISEASE-RESISTANT PLANTS. In an urban landscape, appropriate site selection and use of pest- or disease-resistant plant materials can reduce severity of pest or disease outbreaks. Pest- or disease-resistant plants are expected to reduce the use of pesticides. In addition, installation of resistant plants should increase homeowner or client satisfaction with the aesthetic quality of their landscape surroundings. Within ornamental production systems, a steady consumer demand for plant cultivars and species that are resistant to pests and diseases will likewise reduce the need for preventative pesticide applications to nursery and greenhouse stock. Because disease- and pest-resistant plants are well suited to sustainable landscapes and production systems, they are an important component of an IPM program. Yet, challenges remain to find effective educational outlets and efficient paths for information transfer, such as the use of garden writers and landscape architects, to increase consumer awareness of resistant plant varieties (Garber and Bondari, 1992; 1998).

In fact, the need to educate consumers, growers, and landscape managers about resistant plants and IPM procedures is frequently cited as an information gap that has limited their acceptance (Latimer et al., 1996; Raupp et al., 1989; Wearing, 1988). Awareness of this information gap corresponds with the limited percent of survey respondents who indicated that they [knew] a little about or could explain integrated-pest-management (IPM), which ranged from $24 \%$ of the respondents in Jackson to $40 \%$ in Detroit. For respondents in all four locations, the highest percentages associated with knowledge of IPM-related terms occurred with organic farming and pest scouting. Limited recognition of these IPM components, including the terms mycorrhizal fungi and phero- mone trapping, indicate the need for additional educational outreach. Ornamental growers and landscape managers also cite a lack of sufficient educational and resource information about IPM as well as limitations in economic incentives for implementing IPM practices or developing pestresistant plant materials (Latimer et al., 1996).

\section{Conclusions}

This study yields insight regarding the additional amount customers would be willing to pay for a patented dogwood cultivar resistant to powdery mildew. Powdery mildew was recognized by participants as a problem on dogwood trees in all four cities with the highest percentage $(35 \%)$ reported in Nashville. The lower percentage respondents in Detroit who identified dogwood diseases paralleled reports that fewer than half had a dogwood in their landscape. In the other three cities, $72 \%$ or more reported having a dogwood tree. Regardless, consumers were willing to pay a premium for a powdery-mildew-resistant flowering dogwood. While average self-reported values ranged from a low of $\$ 11.87$ in Jackson, to a high average of $\$ 16.38$ in Detroit, responses were consistent across all four locations. Response uniformity supports the proposition that customers are willing to pay a substantially higher price to acquire a flowering dogwood that will maintain a healthy appearance without the use of pesticides. Consumers also identified several characteristics of trees and shrubs, perennials or annuals that are important factors at point-of-purchase. Key purchase considerations included size and shape, ease of maintenance, attractiveness to birds and animals, flower color, flowering season, and leaf color. Sun and shade requirement was an important characteristic to consumers interested in buying shrubs, perennials, or annuals. These features should be emphasized when promoting plant material to potential customers (Amer. Nursery and Landscape Assn., 2000). At point-of-purchase, diseaseor pest-resistant plants that would be incorporated into an IPM program or sustainable landscape should display graphic images of organisms that are recognized as being environmentally friendly.

Literature cited 
American Nursery and Landscape Association. 2000. The 2000 Grapevine Survey. Colburn House Publ., Wash., D.C.

Badenhop, M.B., W.T. Witte, and T.E. Glasgow. 1985. Production systems and costs for producing balled and burlapped trees of dogwood cultivars, Tennessee, 1984. Tenn. Agr. Expt. Sta. Bul. 637.

Becker, W.A., B.K. Behe, J.L. Johnson, C.D. Townsend, and K.K. Litzenberg. 1997. Consumer perceptions of service quality in the Texas retail floral industry. HortScience 32:318-323.

Davis, M. 1997. Trees still dying-Half of Smokies' dogwoods gone. Knoxville News Sentinel, 23 Feb., p. 25.

Dirr, M.A. 1998. Manual of woody landscape plants. $5^{\text {th }}$ ed. Stipes Publ., Champaign, Ill.

Englander, L. 1990. Dogwood blight. Amer. Nurseryman 172:89.

Centers for Disease Control. 1994. Epi Info users' manual, version 6.04. CDC Epidemiology Program Office. Atlanta, Ga.

Garber, M.P. and K. Bondari. 1992. Landscape architects as related to the landscape/nursery industry: I. Impact on demand for plant material. J. Environ. Hort. 10:69-72.

Garber, M.P. and K. Bondari. 1998. Characteristics of garden writers and their information sources. J. Environ. Hort. 16: 207-211.

Klein, L.A., M.T. Windham, and R.N. Trigiano. 1998. Natural occurrence of Microsphaera pulchra and Phyllactinia guttata on two Cornus species. Plant Dis. $82: 383-385$.

Klingeman, W.E., S.K. Braman, and G.D. Buntin. 2000. Evaluating grower, landscape manager and consumer perceptions of azalea lace bug (Heteroptera: Tingidae) feeding injury. J. Ecol. Entomol. 93: $141-148$.

Latimer J.G., R.D. Oetting, P.A. Thomas, D.L. Olson, J.R. Allison, S.K. Braman, J.M. Ruter, R.B. Beverly, W. Florkowski, C.D.
Robacker, J.T. Walker, M.P. Garber, O.M. Lindstrom, and W.G. Hudson. 1996. Reducing the pollution potential of pesticides and fertilizers in the environmental horticulture industry: I. Greenhouse, nursery, and sod production. Hort Technology 6: 115-124.

Ranney, T.G., L.F. Grand, and J.L. Knighten. 1995. Susceptibility of cultivars and hybrids of kousa dogwoods to dogwood anthracnose and powdery mildew. J. Arboricult. 21:11-16.

Raupp, M.J., M.F. Smith, and J.A. Davidson. 1989. Educational, environmental, and economic impacts of integrated management programs for landscape pests, $\mathrm{p}$. 77-83. In: A.R. Leslie and R.L. Metcalf (eds.). Integrated pest management for turfgrass and ornamentals. U.S. Environ. Protection Agency, Wash., D.C.

SAS Institute. 1985. SAS user's guide: Statistics. $5^{\text {th }}$ ed. SAS Inst., Cary, N.C.

U.S. Dept. Agr. 1998 Census of horticultural specialties. Natl. Agr. Stat. Serv., Wash., DC. 10 Sept. 2003. <http: //www.nass.usda.gov/census/census97/ horticulture/horticulture.htm>.

van der Sluis, E., M. Dierson, and T. Dobbs. 2002. Agricultural biotechnology: farm level, market, and policy considerations. J. Agribus. 20:51-66.

Wearing, C.H. 1988. Evaluating the IPM implementations process. Annu. Rev. Entomol. 33:17-38.

Wertenbroch, K. and B. Skiera. 2002. Measuring consumers' willingess to pay at point of purchase. J. Marketing Res. 39:228-24l.

Windham, M.T. 1996. Resistance to powdery mildew in flowering dogwood. Proc. S. Nursery Assoc. Res. Conf. 41: 197-199.

Windham, M.T. and W.T. Witte. 1998. Naturally occurring resistance to powdery mildew in seedlings of Cornus florida. J. Environ. Hort. 16:173-175.

Windham, M.T., W.T. Witte, and R.N. Trigiano. 2003. Three white-bracted cultivars of Cornus florida that are resistant to powdery mildew. HortScience 38 : 1253-1255.

Witte, W.T., M.T. Windham, R.N. Trigiano, J.A. Skinner, W.E. Klingeman, J.F. Grant, E.T. Graham, P.C. Flanagan, and R.M. Augé. 1999. The dogwood improvement program at the University of Tennessee. Combined Intl. Plant Prop. Soc. 49:71-74. 